\title{
Effect of Kinds of Hay Given to Sheep on Rumen Degradability of Protein of Various Hays
}

\author{
H.E.M. Kamel, Junjiro Sekine, Tetsuyuki SugA* \\ and Ziro MORITA \\ Department of Veterinary Science, Faculty of Agriculture, \\ Tottori University, Tottori-shi 680 \\ * Department of Veterinary Science, Faculty of Agriculture, \\ Yamaguchi University, Yamaguchi-shi 753
}

(Received June 14, 1994)

\begin{abstract}
Four kinds of hay (Italian ryegrass, IR ; bermudagrass, BG ; Sudangrass, SG and alfalfa, AL) were given ad libitum to wethers in a Latin square design in order to determine the effects of diet on the degradability (dg) of hay protein. Ruminal degradation of hay protein was determined by the in situ technique. The passage rate of ruminal digesta was measured using a chromium-mordanted neutral detergent fiber. The dg values did not differ significantly when they were determined under the feeding of different hays as a sole diet. Mean dg values showed relatively large variation under the feeding of different hays. The $\mathrm{dg}$ value of hay protein appeared to show smaller variation under feeding of the same hay as that of the incubated sample. $\mathrm{AL}$ feeding tended to cause larger variation in the $\mathrm{dg}$ values of grass hays. A relatively high correlation was found between dg values and crude protein (CP) digestibility and dry matter degradability. The approximate $\mathrm{dg}$ value of forage protein ( $\mathrm{d} \mathrm{g}_{\mathrm{cP}}$ ) may be estimated by the following equation, with $\mathrm{CP}$ digestibility $\left(\mathrm{CP}_{\mathrm{DIG}}\right)$ as a variable; $\mathrm{dg} \mathrm{CP}=0.195+0.86( \pm 0.14) \mathrm{CP}$ dig, $\mathrm{r}^{2}=$ 0.669 , s.e. \pm 0.012 .
\end{abstract}

Anim. Sci. Technol. (Jpn.) 66 (1) : 36-42, 1995

Key words : dg value, hay protein, hay feeding, CP digestibility

Roughage as a basal feed for ruminants must be estimated for its rumen degradability of protein, even though the concentration of protein is low compared with protein supplement feedstuffs. In situ ruminal digestion of protein has been routinely performed to evaluate the protein degradabilty ( $\mathrm{dg}$ ) of feedstuffs. The dg values of dietary protein have exclusively evaluated in protein supplement feedstuffs ${ }^{2,7,10)}$ or in protein in concentrates ${ }^{11)}$. The evaluation of protein $\mathrm{dg}$ values for roughage has not been well established. ZHAO and FuJita ${ }^{14)}$ claimed that the estimation of $\mathrm{dg}$ values of protein in roughage is needed for diverse kinds of roughage in relation to the establishment of dietary factors affecting the estimation of $\mathrm{dg}$ values. IRIKI et al. ${ }^{7)}$ also pointed out that the effects of the physical and chemical characteristics of feed should be elucidated to establish a technique to determine the $\mathrm{dg}$ value of protein. It has been suggested that the chemical composition of conserved forages influences the determination of the dg value ${ }^{3)}$. Fibrous components have been assessed to be the most effective in the determination of the $\mathrm{dg}$ value $^{3)}$. Differences in the chemical and physical characteristics of feed to be determined by the in situ technique may influence the determination 


\section{Dietary Influence on Protein Degradability Determination}

of the $\mathrm{dg}$ value of diverse kinds of feed as pointed out by IRIKI et $a l^{7}{ }^{7}$. A ration for a test animal may affect the determination of the $\mathrm{dg}$ value of feed to be evaluated ${ }^{2,7,9,11)}$. There is a little information about the effects at a ration given to an aminal on the $\mathrm{dg}$ value of a feedstuff determined by the in situ technique. Thus, the effects of a ration should be elucidated for the determination of protein $\mathrm{dg}$ in feedstuffs.

The present study aimed to determine the effects of various kinds of hay given to sheep on the $\mathrm{dg}$ values of protein in those hays.

\section{Materials and Methods}

The animals used were 4 Suffolk $\times$ Corriedale wethers fitted with rumen cannula and weighing $40 \mathrm{~kg}$ on average. They were individually kept in a metabolism crate. The diets used were Italian ryegrass 1st cut hay (IR), bermudagrass hay (BG), Sudangrass hay (SG) and alfalfa hay (AL). The experimental design was a $4 \times 4$ Latin square with a 28 -day period. Diets chopped to $4 \mathrm{~cm}$ and drinking water were given ad libitum in each period with free access to mineralized salt blocks.

Digestion trials were carried out for 5 days from the 15th to the 19th day of the experimental period using the total collection method. Diets, feed refusals and feces were weighed daily and aliquot samples were made in a composite sample for ecah animal. Samples were dried in a forced-air oven at $55{ }^{\circ} \mathrm{C}$ and were then ground through a $1 \mathrm{~mm}$ screen for further analysis. Dry matter (DM) and nitrogen were analyzed by the methods of $\mathrm{AOAC}^{1)}$. Neutral detergent fiber (NDF) was determined via the method described by GoERING and VAN SoEST ${ }^{4)}$. The live weight of each animal was measured at the beginning and at the end of each experimental period.

On the 20th day of each period, $20 \mathrm{~g}$ of chromium oxide mordanted NDF were administered in the the rumen through the cannula at $7: 00$ in the morning. Feces were then collected at the interval of 4 hours for 2 days and thereafter at 8 hour intervals for 3 days. The feces collected were stored at $20^{\circ} \mathrm{C}$ for further analysis. The chromium concentration in feces was determined by the method described by Yoshida et al. ${ }^{12)}$. The rate constant of ruminal passage $\left(k_{P}, \mathrm{~h}^{-1}\right)$ was estimated by the method presented by Grovum and Williams ${ }^{5)}$.

The rumen degradation of DM and crude protein $(\mathrm{CP})$ was determined using the in situ technique on days 25 to 28 of each experimental period. Four kinds of hay given to animals were ground through a $2 \mathrm{~mm}$ screen and $2 \mathrm{~g}$ of each hay were placed in a nylon bag. The bag used was $5 \times 10 \mathrm{~cm}$ in size with a pore size of $0.045 \mathrm{~mm}$. The bags were soaked in running tap water for 2 hours just before incubation started. Duplicated samples were incubated in the rumen for $6,12,24$ and 48 hours. After incubation, the bags were retrieved from the rumen and were vigorously washed with tap water to eliminate the ruminal digesta on their surface and then in running water until the wash-out water had become clear for several hours. After being washed, the residues in the bag were dried in a forced-air oven at $55^{\circ} \mathrm{C}$ and then to a constant weight at $105^{\circ} \mathrm{C}$ to determine residual DM. Residual CP was then determined by the Kjeldahl method. To determine the quantity of DM invaded in the bag in the course of ruminal incubation, the empty bags with weight $(11 \mathrm{~g})$ were also incubated in the rumen in the same manner as described above. The sample residues in the bag were corrected for the quantities of DM invaded in the bag at a corresponding incubation time.

The kinetics of CP degradation in the rumen were calculated using the following model of a first order kinetic equation ${ }^{8)}$.

$$
\mathrm{P}(\mathrm{t})=\mathrm{D} \cdot \mathrm{e}^{-k \mathrm{t}}+\mathrm{U} \text {, }
$$

where $P(t)=$ residual $C P$ at a given incubation time (t), $\mathrm{D}=$ slowly degradable fraction of $\mathrm{CP}, k$ $=$ degradation rate constant, $\mathrm{U}=$ indigestible fraction of $\mathrm{CP}$. The calculation was pro- 


\section{Kamel, Sekine, Suga and Morita}

secuted by the nonlinear iterative least square method. Readily degradable fraction (R) was then calculated by subtracting the sum of $D$ and $\mathrm{U}$ from 1.

Statistical analyses were made according to the Latin square method presented by YOSHIDA ${ }^{13)}$.

\section{Results}

Table 1 shows the mean DM intake and mean live weight of animals used in the present study together with DM, NDF and CP content and corresponding digestibility for hay given to animals. Mean DM intake for AL and BG were significantly greater than that of IR ( $P$ $<0.05$ ). Alfalfa hay contained significantly less NDF and more $\mathrm{CP}$ than grass hays $(\mathrm{P}<$ 0.01 ). Mean NDF content was not significantly different among grass hays. BG and SG contained significantly more $\mathrm{CP}$ than did $\mathrm{IR}(\mathrm{P}<$ $0.01)$ and the digestibility of $\mathrm{CP}$ for $\mathrm{BG}$ and $\mathrm{SG}$ was higher than that for IR. The digestibility of $\mathrm{CP}$ for $\mathrm{AL}$ was significantly higher than those for grass hays $(\mathrm{P}<0.05)$.

Mean values with standard deviation for $\mathrm{dg}$ of $\mathrm{CP}$ are presented in Table 2 for IR, BG, SG and AL determined via the in situ technique when feeding each hay. The dg values of hay protein did not differ significantly among measurements when feeding a single hay diet. The $\mathrm{dg}$ values determined when feeding DG and SG, however, tended to be higher than those determined when feeding IR and $A L$ as shown in Fig. 1. The dg value of $\mathrm{CP}$ of $\mathrm{AL}$ was significantly higher than those of grass hays when compared using pooled mean values $(\mathrm{P}<0.01)$. There was no statistically significant difference in $\mathrm{dg}$ values among grass hays. The standard deviation showed a relatively wide margin for each mean value determined when feeding any single hay. When feeding $\mathrm{AL}$, the dg values of grass hays showed a greater standard deviation than those determined when feeding grass hays. The $\mathrm{dg}$ value of each hay protein appeared to have a smaller standard deviation when it was determined via feeding of the same hay as the in situ sample.

The $\mathrm{dg}$ values of $\mathrm{CP}\left(\mathrm{dg}_{\mathrm{CP}}\right)$ were significantly and positively correlated with the digestibilities of $\mathrm{CP}\left(\mathrm{CP}_{\mathrm{dig}}\right)$ of corresponding hay $(\mathrm{r}=$ $0.818, \mathrm{P}<0.01)$. The following regression equation was obtained; $\mathrm{dg}_{\mathrm{CP}}=0.195+0.86( \pm 0.14)$

Table 1. Mean dry-matter intake and mean live weight of animals used, and composition and digestibility of Italian ryegrass hay, bermudagrass hay, Sudangrass hay and alfalfa hay

\begin{tabular}{lcccc}
\hline \hline & \multicolumn{4}{c}{ Diets } \\
\cline { 2 - 5 } & $\mathrm{IR}^{\mathrm{b}}$ & $\mathrm{BG}$ & $\mathrm{SG}$ & $\mathrm{AL}$ \\
\hline DM intake, $\mathrm{kg} / \mathrm{day}$ & $0.83^{\mathrm{a} 2 \mathrm{2}} \pm 0.25^{3)}$ & $1.30^{\mathrm{b}} \pm 0.23$ & $0.86^{\mathrm{ab}} \pm 0.50$ & $1.40^{\mathrm{b}} \pm 0.30$ \\
Live weight, $\mathrm{kg}$ & $40.0 \pm 4.0$ & $40.0 \pm 4.0$ & $39.3 \pm 2.6$ & $40.0 \pm 4.0$ \\
Composition of hay & & & & \\
Dry matter, \% & $85.7 \pm 2.0$ & $88.4 \pm 4.0$ & $87.9 \pm 3.0$ & $87.0 \pm 3.0$ \\
NDF, \%DM & $65.8^{\mathrm{a}} \pm 3.0$ & $71.5^{\mathrm{a}} \pm 5.0$ & $69.7^{\mathrm{a}} \pm 3.0$ & $45.0^{\mathrm{b}} \pm 5.0$ \\
Crude protein, \%DM & $6.7^{\mathrm{a}} \pm 0.5$ & $8.6^{\mathrm{b}} \pm 0.4$ & $9.0^{\mathrm{b}} \pm 0.8$ & $18.7^{\mathrm{c}} \pm 2.8$ \\
Digestibility & & & & \\
Dry matter, \% & & & & \\
NDF, \% & $63.0^{\mathrm{a}} \pm 5.0$ & $59.1^{\mathrm{ab}} \pm 1.9$ & $55.0^{\mathrm{b}} \pm 3.0$ & $64.6^{\mathrm{a}} \pm 0.9$ \\
Crude protein, \% & $65.0^{\mathrm{a}} \pm 7.0$ & $58.0^{\mathrm{ab}} \pm 5.0$ & $57.0^{\mathrm{ab}} \pm 4.0$ & $51.0^{\mathrm{b}} \pm 8.0$ \\
\hline
\end{tabular}

1) Abbreviated notations are as follows : IR, Italian ryegrass hay ; $B G$, bermudagrass hay ; $S G$, Sudangrass hay; AL, alfalfa hay ; DM, dry matter and NDF, neutral detergent fiber.

${ }^{2)}$ Figures in the same row with different superscripts differ significantly $(\mathrm{P}<0.05)$.

${ }^{3}$ Mean + standard deviation 


\section{Dietary Influence on Protein Degradability Determination}

Table 2. The rumen degradability $(\mathrm{dg})$ of crude protein for Italian ryegrass hay (IR), bermudagrass hay (BG), Sudangrass hay (SG) and alfalfa hay ( $A L$ ) determined under feeding of various hays by in situ technique

\begin{tabular}{lcccc}
\hline \multirow{2}{*}{$\begin{array}{c}\text { Hay } \\
\text { given to } \\
\text { animals }\end{array}$} & \multicolumn{5}{c}{ Hay incubated in the rumen } \\
\cline { 2 - 5 } & $\mathrm{IR}$ & $\mathrm{BG}$ & $\mathrm{SG}$ & $\mathrm{AL}$ \\
\hline $\mathrm{IR}$ & $0.68 \pm 0.04^{\mathrm{l}}$ & $0.60 \pm 0.11$ & $0.66 \pm 0.09$ & $0.82 \pm 0.08$ \\
$\mathrm{BG}$ & $0.77 \pm 0.08$ & $0.65 \pm 0.05$ & $0.75 \pm 0.08$ & $0.90 \pm 0.03$ \\
$\mathrm{SG}$ & $0.71 \pm 0.09$ & $0.71 \pm 0.07$ & $0.72 \pm 0.09$ & $0.89 \pm 0.06$ \\
$\mathrm{AL}$ & $0.66 \pm 0.13$ & $0.67 \pm 0.21$ & $0.64 \pm 0.11$ & $0.86 \pm 0.06$ \\
Pooled & $0.70^{\mathrm{a} 2} \pm 0.09$ & $0.66^{\mathrm{a}} \pm 0.11$ & $0.69^{\mathrm{a}} \pm 0.09$ & $0.87^{\mathrm{b}} \pm 0.06$ \\
\hline
\end{tabular}

Abbreviated notations are the same as Table 1.

1) Mean \pm standard deviation

${ }^{2)}$ Mean values of pooled results with different superscripts differ significantly $(\mathrm{P}<0.01)$.

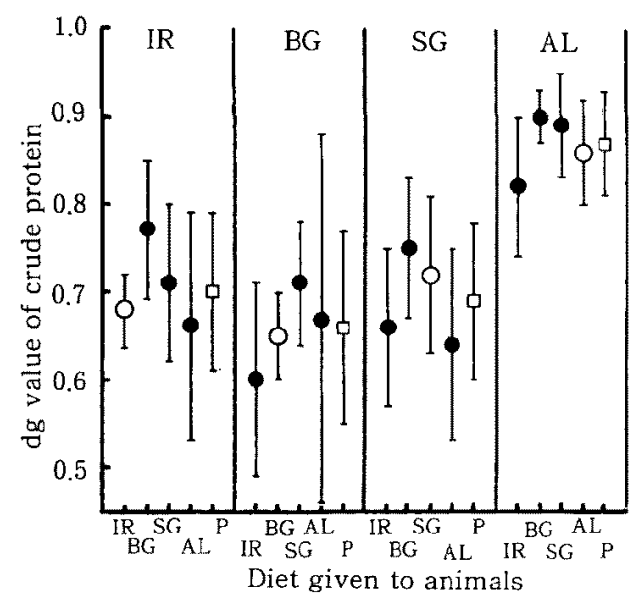

Fig. 1. Mean dg values of hay protein determined under feeding of Italian ryegrass hay (IR), bermudagrass hay (BG), Sudangrass hay (SG) and alfalfa hay (AL), and pooled mean (P).

Open circles $(O)$ show the values determined under feeding of the same hay as incubated samples and solid circles (O) show those determined under feeding of different hays. Open squares $(\square)$ are the pooled mean for each hay protein.

Vertical lines show standard deviation of mean.

$C P_{\text {dig }}, r^{2}=0.669$, s.e +0.012 . The dg values of $C P$ $\left(d g_{C P}\right)$ also correlated significantly with the $d g$ values of DM ( $\left.\mathrm{dg}_{\mathrm{DM}}\right)$ calculated in the same manner as $C P(r=0.729, P<0.01)$. The regres- sion equation obtained was as follows ;

$d g_{C P}=0.15+0.94( \pm 0.23) d g_{D M}, \quad r^{2}=0.531, \quad$ s.e. \pm 0.016 .

Table 3 shows the passage rate of ruminal digesta $\left(k_{P}, \mathrm{~h}^{-1}\right)$ for IR, BG, SG and AL. No significant difference was found for $k_{p}$ among any hays. The $k_{P}$ values of $\mathrm{BG}$ and $\mathrm{SG}$, however, tended to be smaller than those of $\mathrm{AL}$ and IR, although the difference was very minute.

\section{Discussion}

Although diets were offered ad libitum, sheep ate less IR than AL or BG. It has been well documented that the quality of roughage is one of the most important determinants of roughage intake ${ }^{6}$. The quality of roughage is generally assessed by $\mathrm{CP}$ and fiber content. A lower CP content in IR may be responsible for lower DM consumption. Bermudagrass hay and $\mathrm{SG}$ contained lower $\mathrm{CP}$ and higher NDF than did AL. No significant difference was found among $D M$ intake for $B G, S G$ and $A L$. $\mathrm{CP}$ and NDF content alone did not appear to be a limiting factor for feed intake.

The $d g$ values of hay protein were found to show no significant difference when determined via the feeding of different hays. FUJiTA et al. ${ }^{2)}$ observed no significant influence of the type of forage offered to animals for 
Table 3. The passage rate of rumen digesta $\left(k_{\hbar}, \mathrm{h}^{-1}\right)$ of sheep given Italian ryegrass hay, bermudagrass hay, Sudangrass hay and alfalfa hay determined by chromium mordanted neutral detergent fiber

\begin{tabular}{|c|c|c|c|c|}
\hline & IR & $\mathrm{BG}$ & SG & $\mathrm{AL}$ \\
\hline$k_{p} \mathrm{~h}^{-1}$ & $0.014 \pm 0.008^{13}$ & $0.013 \pm 0.006$ & $0.013 \pm 0.009$ & $0.018 \pm 0.007$ \\
\hline
\end{tabular}

determinating the $\mathrm{dg}$ of forage protein, when wethers were given either grass hay, grass silage or corn silage. Similar results were observed when feeding different kinds of hays in the present study. Therefore, $d g$ values of hay protein appear to be determined when feeding different types of hay as a sole diet. Mean values, however, showed a relatively large variation when determined under different hay feeding condition (Fig. 1). The dg values showed a relatively smaller standard deviation when determined via feeding of the same hay. The $\mathrm{dg}$ value of a hay protein should be determined under feeding of the same hay to minimize variation. The dg value of $\mathrm{CP}$ in grass hay showed greater variation when determined via the feeding of $\mathrm{AL}$ than via grass hays. When mean $\mathrm{dg}$ values for grass-hay protein were estimated without results obtained via AL feeding, the magnitude of standard deviation was lowered to $50 \%$ of the pooled values shown in Table 2 without any significant change in mean values. It is suggested that the determination of dg values for grass hay should not be carried out via the feeding of a legume hay with high CP content.

A relatively large standard deviation for each mean dg calculated suggests that variation due to other effects such as animal or replication may have concealed the precise effect of the diet. The dg of hay protein determined when feeding $B G$ and SG tended to be higher than that of AL and IR (Table 2). This phenomenon suggests that there are effects of passage rate ${ }^{7)}$, chemical composition ${ }^{3)}$ and the physical characteristics of forage ${ }^{7}$. A slower rate of passage for $B G$ or $S G$ may have caused a higher dg estimation than that determined via feeding of other varieties, although the results of the present study show no clear evidence. The results of our other experiment indicated that brittleness with abrasion or cutting appeared to be lower in BG or SG than in AL or IR (unpublished data). This difference in brittleness among hays may undermine the ruminal passage rate of corresponding forage, resulting in a biased determination of $\mathrm{dg}$. The bias is assumed to range from 7 to $17 \%$ when the cocfficients of variation of the pooled mean dg values presented in Table 2 are considered.

Some attempts have been made to facilitate the estimation of $\mathrm{dg}$ values for dietary protein by using the results of ruminal incubation ${ }^{\text {7) }}$ and the chemical composition of a diet ${ }^{33}$. In the present study, an attempt to estimate the dg value of forage protein was made by using the digestibility of $\mathrm{CP}$ and degradability of DM in the rumen. This estimation appears feasible by using the two parameters studied in the present study. The coefficients of determination, however, revealed that the equation may not eatimate the dg value with high precision by using the digestibility of $\mathrm{CP}$ or degradability of DM. The equations may be utilized for an approximation of the $\mathrm{dg}$ value of protein in hay that has not been determined.

From the results and discussion, it is concluded that feeding different kinds of hay has no considerable effect on the determination of the $\mathrm{dg}$ value of hay protein, even though there is a possible 7 to $17 \%$ variation. To minimize the variation in the $d g$ value of hay protein, it is suggested that the determination be carried out when feeding the same hay or hay with 
Dietary Influence on Protein Degradability Determination

similar CP content. An approximate $d g$ value for hay protein may be possible by using the digestibility of crude protein determined when feeding the corresponding forage as a sole diet.

\section{Acknowledgements}

The authors gratefully acknowledge Mr. R. OURA for his assistance in carrying out this experiment.

\section{References}

1) Association of Official Analytical Chemists, Official Methods of Analysis. 11th ed. 122-131. A.O.A.C., Washington DC. 1970.

2) Fujita, H., S. Matsuoka, J. Takahashi, T. YUhKI and S. KAMANO, Effect of the diet on the in situ degradability of the forage protein in the rumen. Jpn. J. Zootech. Sci., $59: 510-516$. 1988.

3) Fúnita, H., S. Matsuoka, J. Takahashi and N. KUMASE, Relationship between chemical composition and protein degradability of conserved forages. Anim. Sci. Technol. (Jpn.), 62 : 947-954. 1991.

4) Goering, H.K. and P.J. VAN SoEst, Forage Fiber Analyses, Agric., Handbook. No. 379. 1-20. U.S. D.A., Washington DC. 1970.

5) Grovum, W.L. and V.J. Williams, Rate of passage of digesta in sheep. 4. Passage of marker through the alimentary tract and the biological relevance of rate-constants derived from the changes in concentration of marker in faeces. Br. J. Nutr., 30 : 313-329. 1973.
6) GRUBer, L.R. STEINWENDER, K. KRIMBERGER and J. SOLKNER, Roughage intake of Simmental, Brown Swiss and Holstein Friesian cows fed rations with 0,25 and $50 \%$ concentrates. Livest. Prod. Sci., 27 : 123-136. 1991.

7) IRIKI, T., I. OHKAWA and M. ABE, Comparison of susceptibility to degradation of feed proteins in the rumen of a cow fed a high concentrate ration. Jpn. J. Zootech. Sci., 54 : 518-524. 1983.

8) MERTEns, D.R. and J.R. LOFTEN, The effect of starch on forage fiber digestion kinetics in vitro. J. Dairy Sci., 63 : 1437-1446. 1980.

9) NoceK, J.E., In situ and other methods to estimate ruminal protein and energy digestibility : A review. J. Dairy Sci.., $71: 2051-2069.1988$.

10) Окubo, M., M. Hanada, J. Sekine, Y. MiUra and Y. AsArida, The rumen degradability of protein for various feedstuffs. J. Fac. Agr. Hokkaido Univ., $61: 49-53.1986$.

11) Sekine, J., R. Oura and Y. AsahidA, Effects of ratio of concentrate to roughage and kinds of hay in a ration on estimating the rumen degradability of protein of formulated concentrate. AJAS, 5 : 19-24. 1992.

12) Yoshida, M., $K, \operatorname{Kosaka}, S$. Horril and $K$. KametaKa, A new procedure for the chromic oxide with potassium phosphate reagent. Japan. Poultry Sci., 4 : 24-29. 1967.

13) YoshidA, M., Design of Experiments for Animal Husbandry. 101-111. Yokendo, Tokyo. 1989.

14) ZHAO, J. and H. FuJiTA, The effect of different types of dietary protein and energy on the rumen degradability of forage protein in silu. Jpn. J. Zootech. Sci., 60 : 22-28. 1989. 


\title{
乾草蛋白質の第一胃内分解率に及ぼす給与乾草の影響
}

\author{
H.E.M. K KAMEL ・関根純二郎・管 徹行* ・森田一郎 \\ 鳥取大学農学部, 鳥取市 680 \\ *山口大学農学部, 山口市 753
}

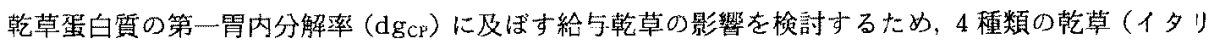
アンライグラス，IR；バーミューダグラス， BG；スーダングラス， SG およびアルフォルファ，AL）を ラテン方格法によりめん羊に自由採食させた。乾草蛋白質の第一胃内分解は, in situ 法により測定し た。第一胃内容物の通過速度は，クロムで媒染した中性デタージェント瀻維により測定した。乾草単独 給与時に乾草蛋白質の第一胃内分解率を測定した場合, 給与乾草による測定値の有意な暹いは認められ なかった，各乾草給与の測定の平均值には，比较的大きな变動か認められた．湘定試料と问じ乾草を給

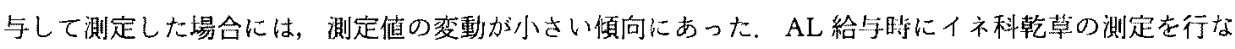
うと，測定㯈の变動が大きくなる倾向にあった，粗蛋白質の消化率および乾物の第一胃内分解率と $\mathrm{d} g$ 価之の間に比較的高い相関関係が認められた。推定精度は低いが, 乾草蛋白質の第一胃内分解率 $\left(\mathrm{dg}_{\mathrm{cP}}\right)$ の概数値を粗蛋白質の消化率 ( $\left.\mathrm{CP}_{\mathrm{dig}}\right)$ から以下の式で算定できる.
\end{abstract}

$$
\mathrm{dg}_{\mathrm{CP}}=0.195+0.86( \pm 0.14) \mathrm{CP}_{\mathrm{dig}}, \mathrm{r}^{2}=0.669 \text {, s.e. } \pm 0.012 \text {. }
$$

日畜会報， $66(1): 36-42 ， 1995$ 